\title{
The Effects of Mind Games on Higher Level Thinking Skills in Gifted Students*
}

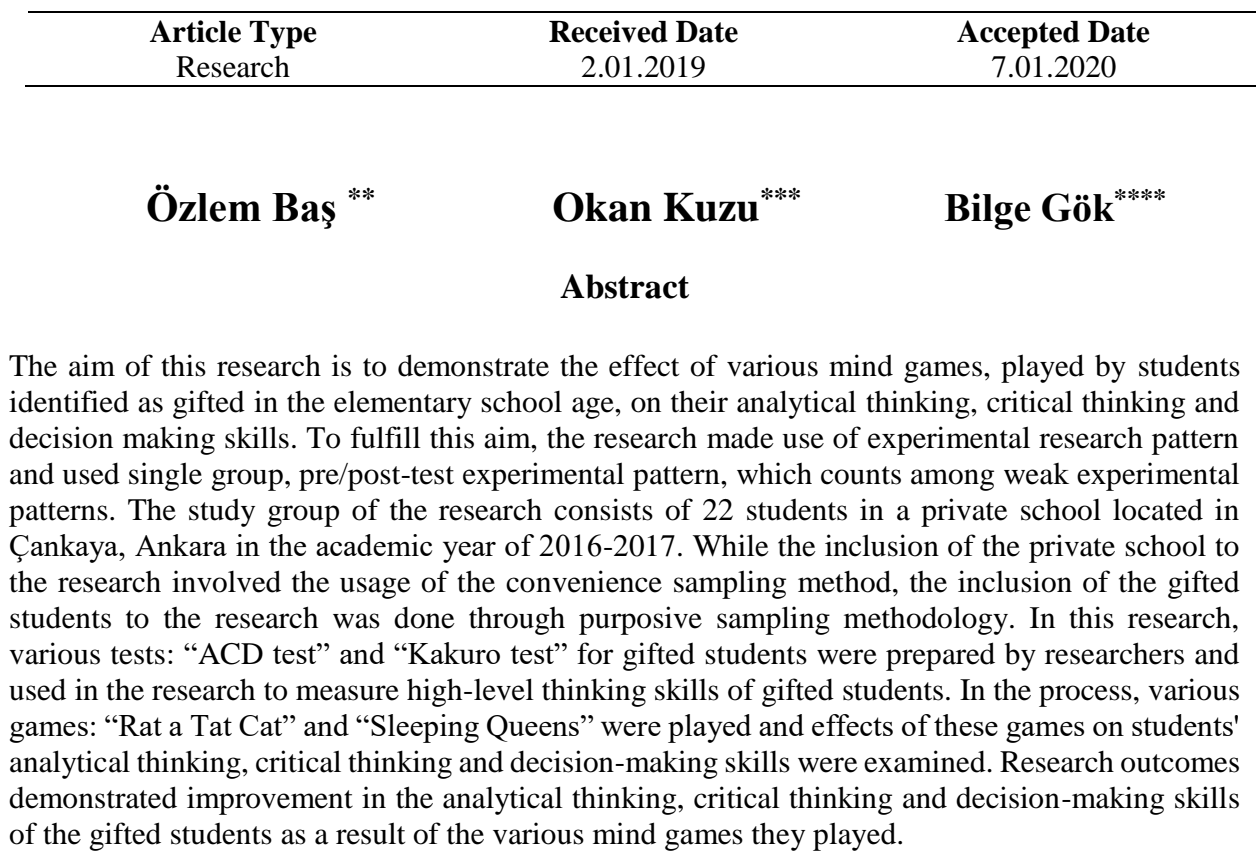

Keywords: Mind games, gifted students, analytical thinking, critical thinking, decision-making.

\footnotetext{
"The study was presented in "International Conference on Mathematics and Mathematics Education (ICMME-2017)", Şanlıurfa, Turkey, May 11-13, 2017. Moreover, the study was supported by the Scientific Research Projects Coordination Unit of Hacettepe University. Project Code: SDS-2015-8831. We would like to thank Nesibe Aydin Schools for providing environment.

** Corresponding Author: Associate Professor, Hacettepe University, Education Faculty, Elemantary Education Department, Ankara, Turkey. ozlembas@ hacettepe.edu.tr https://orcid.org/0000-0002-0716-103X

*** Assistant Professor, Kirsehir Ahi Evran University, Education Faculty, Mathematic and Science Education Department, Kirsehir, Turkey. okan.kuzu@ahievran.edu.tr https://orcid.org/0000-0003-2466-4701

${ }^{* * * *}$ Associate Professor, Hacettepe University, Education Faculty, Elemantary Education Department, Ankara, Turkey, bilgeb@hacettepe.edu.tr https://orcid.org/0000-0002-1548-164
} 


\title{
Özel Yetenekli Öğrencilerle Oynanan Zekâ Oyunlarının Üst Düzey Düşünme Becerilerine Etkisi*
}

\begin{tabular}{ccc}
\hline $\begin{array}{c}\text { Makale Türü } \\
\text { Araştırma }\end{array}$ & $\begin{array}{c}\text { Başvuru Tarihi } \\
2.01 .2019\end{array}$ & $\begin{array}{c}\text { Kabul Tarihi } \\
7.01 .2020\end{array}$ \\
\hline Özlem Baş $^{* *}$ & & \\
& Okan Kuzu & \\
& $\ddot{O ̈ z}^{* * *}$ & Bilge Gök
\end{tabular}

\begin{abstract}
Bu araştırmanın amacı ilkokul çağındaki tanılanmış özel yetenekli öğrencilerle oynanan çeşitli zekâ oyunlarının analitik düşünme, eleştirel düşünme ve karar verme becerilerine olan etkisini ortaya koymaktır. Bu amaç doğrultusunda deneysel araştırma deseni kullanılan çalışmada zayıf deneysel desenlerden tek grup ön test-son test deneysel desen kullanılmıştır. Araştırmanın çalışma grubunu 2016-2017 eğitim öğretim yılında Ankara ilinin Çankaya ilçesindeki özel bir okulda öğrenim gören 22 özel yetenekli öğrenci oluşturmaktadır. Özel okulun araştırmaya dâhil edilmesinde uygun örnekleme yöntemi, bu okuldaki özel yetenekli öğrencilerin araştırmaya dâhil edilmesinde ise amaçsal örnekleme yöntemi kullanılmıştır. Araştırmacılar tarafından özel yetenekli öğrencilerin üst düzey düşünme becerilerini ölçmek amaciyla ön ve son test olarak "AKE" testi ve "Kakuro testi" hazırlanmıştır. Uygulama sürecinde ise "Rat A Tat Cat" ve "Sleeping Queens" oyunları oynatılmış ve bu oyunların öğrencilerdeki analitik düşünme, eleştirel düşünme ve karar verme becerilerine olan etkisi incelenmiştir. Araştırma sonucunda özel yetenekli öğrencilerle oynanan zeka oyunlarının özel yetenekli öğrencilerin analitik düşünme, eleştirel düşünme ve karar verme becerilerini geliştirdiği görülmüştür.
\end{abstract}

Anahtar Sözcükler: Zekâ oyunları, özel yetenekli öğrenciler, analitik düşünme, eleştirel düşünme, karar verme.

\footnotetext{
* Bu çalışma 11-13 Mayıs 2017 tarihleri arasında Şanlıurfa'da düzenlenmiş olan "International Conference on Mathematics and Mathematics Education (ICMME-2017)" isimli konferansta sözlü bildiri olarak sunulmuştur. Ayrıca, bu araştırma Hacettepe Üniversitesi Bilimsel Araştırma Projeleri [BAP] Koordinasyon Birimi tarafindan desteklenmiştir. Proje Kodu: : SDS-2015-8831 Çalışmamıza ortam să̆layan Nesibe Aydın Ĕ̈itim Kurumlarına teşekkür ederiz.

** Sorumlu Yazar: Doç. Dr., Hacettepe Üniversitesi, Eğitim Fakültesi, Temel Eğitim Bölümü, Sınıf Eğitimi Ana Bilim Dalı, ozlembas@ hacettepe.edu.tr https://orcid.org/0000-0002-0716-103X

*** Dr. Öğretim Üyesi, Kırşehir Ahi Evran Üniversitesi, Eğitim Fakültesi, Matematik ve Fen Bilimleri Eğitimi, okan.kuzu@ahievran.edu.tr https://orcid.org/0000-0003-2466-4701

**** Doç. Dr., Hacettepe Üniversitesi, Eğitim Fakültesi, Temel Eğitim Bölümü, Sınıf Eğitimi Ana Bilim Dalı, bilgeb@hacettepe.edu.tr https://orcid.org/0000-0002-1548-164
} 


\section{Introduction}

The most basic need of childhood, play, is in fact the most effective educational medium for the child's intellectual needs when presented in a well-planned and efficacious format. Play passes through progressive stages in the child's learning basic life skills and communicating with his/her environment. Oğurlu and Yaman (2010, p.215) mention that the child learns the duties and responsibilities in the social environment as s/he experiences them during play. They also point out that the roles between mother, father and siblings as well as their behavior towards the elderly and their peers become apparent, as they play. During play, the child reinforces, embraces, acknowledges the notions of human relations, helping, acquiring knowledge, habits and experiences, roles in life. In addition, young gifted students often learn to play by the rules earlier than other students.

When we look at the studies in which play is used in education, it can be observed that games help develop a lot of skills in order for students to use high-level thinking skills. According to Erhan, Hazar and Tekin $(2009$, p.2-8), one of the problems related to students is that they could not get the students to concentrate on a certain subject. In Conelly's (2002) study of the motivational role of collaborative games in the classroom environment, it has been shown that students are much more motivated and more active in academic work when they play collaborative games. In addition, Carpenter (2010) created a sportive experience for students based on the Tactical Gaming Model in his $\mathrm{PhD}$ dissertation on game performance and student motivation with a Frisbee game unit. On the other hand, Polat in his work (2013, p. 23) has discovered that, because students perceive origami activities as a game, this turns mathematics education into fun.

Mind games are used as an effective tool in the development of various mental capacities and skills of the students and turning real problems into fun activities by making them game-like (MoNE, 2013). In addition, it has been emphasized by some researchers that mind games are important in the development of skills such as strategic thinking, logical reasoning, decision-making and data processing (Bottino and Ott, 2006; Kirriemur and McFarlane, 2004). The types of games included in the program and that represent the learning areas of the program are; reasoning and processing games, verbal games, geometric-mechanical games, strategy games, memory games and mind games (MoNE, 2013, p.9-11).

Played by students, these games' contribution to the development of their intellectual skills is immense. These games, when played regularly even for a short period of time, cause the child to start using several strategies and means, and this begs the following question: Which games develop which intellectual skills? In this context, the basic intellectual skills of gifted students are generally divided into two fields, intellectual and academic (Parks, 2009, 261). Intellectual skills include skills such as creative thinking, reasoning, problem solving, analytical thinking, critical thinking, etc. These skills and their fields of development are summarized below. The Parks (2009) Intellectual Domain Map shows that skills are directly or indirectly related to each other. Based on this, it can be said that play improves multiple skills.

The finding that intelligent games improve the $2^{\text {nd }}$ graders 'levels of mental skills obtained by Marangoz and Demirtaş (2017) demonstrates the importance of intelligent games for primary school students. Baki (2018) states that intelligent games improve students' socialization, self-expression, multiple-thinking, directing attention and focusing and problem-solving and recommends that the class of intelligent games should be available at all grade levels. Genç and Dağlığlu (2018, p. 184), on the other hand, point out that the importance of games should also be taken into consideration in the case of gifted students- one of the neglected groups in Turkey- and highlight the importance of games to assure that those students' potentials can be maximized and that they can communicate effectively with other students by also taking into account their developmental differences from other students. Some studies concerning games and gifted students were found as a result of literature review (Altun, 2017; Baki, 2018; Bulut, 2018; Cameron, 2007; Demirel and Karakuş Yılmaz, 2019; Genç and Dağlıoğlu, 2018; Marangoz and Demirtaş, 2017). Moreover, there was not much studies related to use mind games for the gifted students in the literature. It is believed that considering mind games-one of the practices 
to motivate improve gifted students and thus to improve their mental skills will contribute to the literature and that it will be important to educators and teachers in that it gives examples to them.

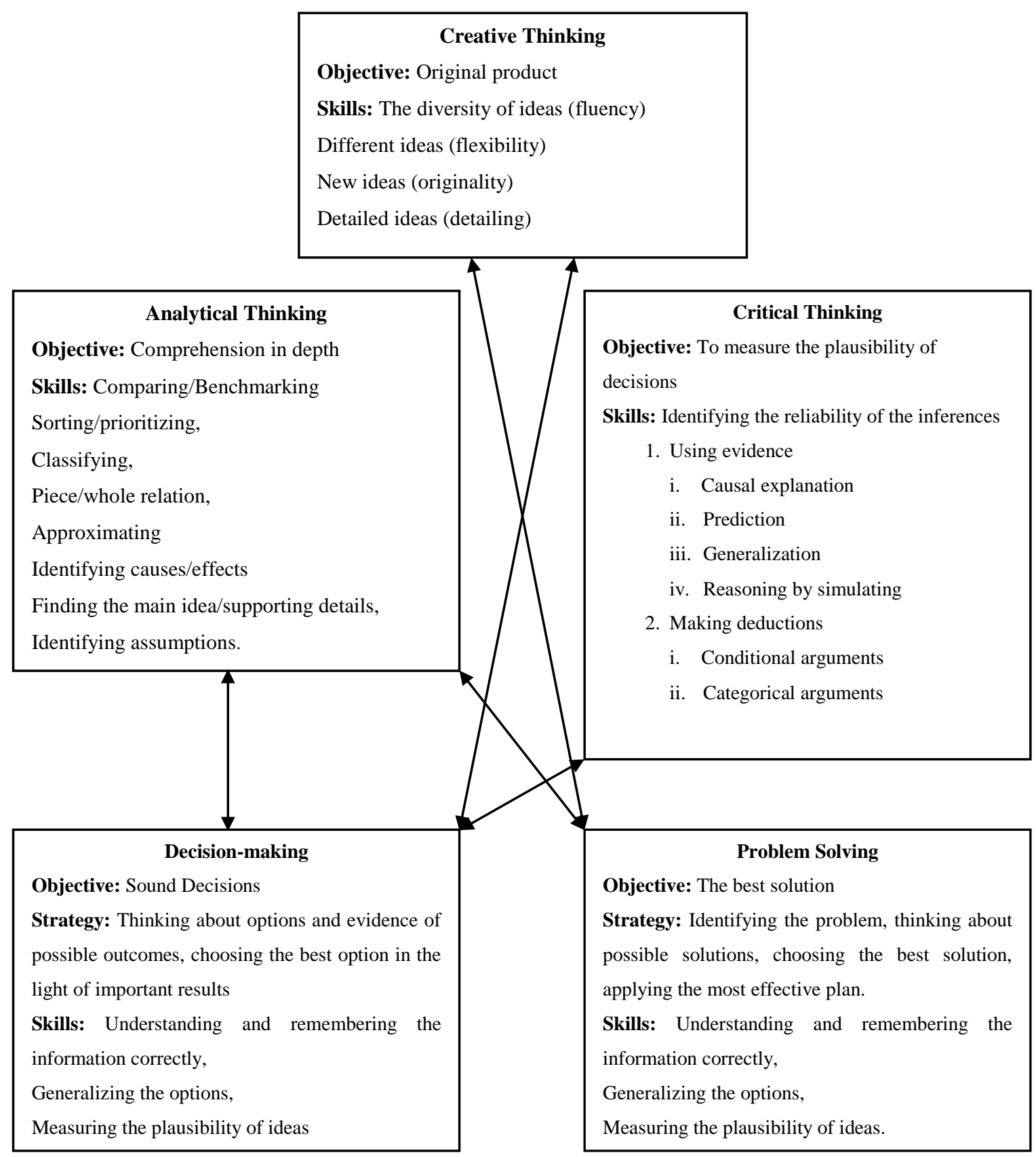

Figure 1. Intellectual Domain Map (Parks, 2009, p.263)

And also, it is thought that this research will allow for the merging of education and game lessons of gifted students, introduce the popular card games abroad which are used in the education of gifted students, show the correlation between these games and the students' intellectual skills and in doing so contribute to the field. In this context, the aim of the research is to demonstrate the influence of various intelligence games played with the identified gifted students in the elementary school age on analytical thinking, critical thinking and decision making skills. 
1. Is there a meaningful difference between pre-test and post-test scores of analytical thinking skills of identified gifted students of primary school age when they play various mind games?

2. Is there a meaningful difference between pre-test and fpost-test scores of critical thinking skills of identified gifted students of primary school age when they play various mind games?

3. Is there a meaningful difference between pre-test and post-test scores of decision-making skills of identified gifted students of primary school age when they play various mind games?

\section{Research Design}

\section{Method}

In this study, one-group pretest-posttest experimental design which is one of weak designs was used to investigate the effect of various intelligence games on gifted elementary school students' development of analytical thinking, critical thinking and decision-making skills. In this pattern, the experimental process is tested with a study on a single group. Measurements of dependent variables of the subjects were obtained by using the same subjects and same measurement tools first as pre-test and later as post-test (Büyüköztürk, Kılıç Çakmak, Akgün, Karadeniz and Demirel, 2012). In the pattern, dependent variables are analytical thinking, critical thinking and decision making skills of gifted elementary school students, and independent variables are intelligence games of various genres whose influence on the analytical thinking, critical thinking and decision making skills of the gifted elementary school students are examined. The symbolic representation of the design is presented in Table 1.

\section{Table 1}

\section{Single group pretest-posttest pattern example}

\begin{tabular}{llll}
\hline Group & Pre-test & Process & Post-test \\
\hline G & O1 & X & O1 \\
& $\begin{array}{l}\text { ACD test and kakuro test } \\
\text { (dependant variable) }\end{array}$ & $\begin{array}{l}\text { Mind games } \\
\text { (Intervention) }\end{array}$ & $\begin{array}{l}\text { ACD test and kakuro test } \\
\text { (dependant variable) }\end{array}$ \\
\hline
\end{tabular}

\section{Research Sample}

The study group of the research consists of 22 students ( 6 females, 16 males) schooling in a private school located in Çankaya, Ankara in the academic year of 2016-2017. They are the $3^{\text {rd }}$ and $4^{\text {th }}$ grade students who have been selected for the weekend school of gifted students by experts through WISC-R and Stanford-Binet intelligence tests. While the inclusion of the private school to the research involved the usage of the convenience/accidental sampling method, the inclusion of the gifted students to the research was done through purposive sampling method.

\section{Research Instruments and Procedures}

In the research, the effects of various mind games: "Rat a Tat Cat" and "Sleeping Queens" on the analytical thinking, critical thinking and decision-making ability of gifted students on students were examined. In this context, reasoning and calculation games, memory games and mind games and their difficulty levels were investigated in the curriculum of MoNE (2013) to measure the high-level thinking skills of gifted students. Within the scope of the game types, various tests: "Analytical thinking, Critical thinking and Decision making skills test (ACD test)", "Kakuro Test" and "Memory Game Test" were prepared according to D1 (Beginner level), D2 (Intermediate level) and D3 (Advanced level) difficulty levels.

\section{Analytical Thinking, Critical Thinking and Decision Making Skills Test (ACD test)}

Firstly, six types of questions were identified by scanning the concerning field and taking expert opinions into account. Five items were prepared with different levels of difficulty from each question type. Mathematics, Turkish language experts and gifted education experts were consulted on the suitability of the content of the 30 items which were prepared, the conformity of the materials with the 
rules of writing, whether there was a scientific error or not, the conformity of the materials with the students' level. Considering these expert opinions, necessary corrections were made and five students in the second level of primary education were asked to read the test item. According to the feedback of the students about the materials, the expressions which were not understood or misunderstood were corrected and the expert opinions were applied once again before the application. In line with the common opinion of the experts, a test consisting of a total of 18 items was prepared in line with the D1 (items 1-6), D2 (items 7-12) and D3 (items 13-18) difficulty levels of each question type. D1 level included items that involve an easy-to-predict solution with a single stage. D2 level included items that involve a hard-to-predict solution with a single stage or games that involve multiple easy stages. D3 level included items that require experience or items which are hard-to-predict with multiple stages. The test was applied to a group of 132 students with similar characteristics to the study group. The obtained data were analyzed in two categories as "right" and "wrong" and analyzed with the "Test Analysis Program" [TAP]. As a result of the analysis, the reliability coefficient of Kuder-Richardson 20 (KR-20) was found to be .828. In addition, the item difficulty index of the test ranged from .07 to .93 and the average difficulty index was calculated as .501. The item difficulty index indicates the correct answer rate for each item and, usually, a value of 0.50 on the item difficulty index is preferred (Çepni et. all, 2008). On the other hand, the item discrimination index of the test ranged from .26 to 1 and the average discrimination index was found to be .525. The item discrimination index is the level of discernment an item can make between students with a high level of achievement and those with a low achievement level. The item discrimination index takes a value between " $-1 "$ and " $+1 "$. Items with a discrimination index of zero or negative cannot be included in the test. If the discrimination index is .40 or higher, the item is very good; between the values of .30 to .40 , the substance is good; if between .20 and .30 , the item can be used as it is or modified if need be. If the value is less than .20 , the substance should not be used or should be reformulated. Accordingly, an item with the value of 0.26 was included in the test by making necessary corrections. Within the framework of these results, the "ACD Test" with 18 items was obtained, which has very good indices of validity, reliability, item difficulty and discrimination.

\section{Memory Game Test and Kakuro Test}

Three Memory Tests with the difficulty levels D1, D2 and D3 were prepared. The numbers and numbers in these memory tests, consisting of $3 \times 2,3 \times 3$ and $4 \times 3$ matrices, respectively, have been chosen carefully according to their difficulty of memorization. At this stage, an interview of the French mathematician and psychologist Nicolas Gauvrit on the impact process was taken into consideration. Gauvrit noted that a multiplication consisting of small numbers such as $2 \times 3,3 \times 4$ and a multiplication process consisting of the same numbers like $5 \times 5,6 \times 6$ can be remembered more easily. In addition, Gauvrit emphasized that multiplication using numbers 5 and 10 would be easier to remember comparatively. Multiplications involving the numbers 6,7 and 8 are harder to keep in memory (Gauvrit, 2014). In this case, the numbers $0,1,2,3,4,5$ are be remembered easily and $6,7,8,9$ are harder to remember. Also, the fact that there are repeating numerals in the number result in the number being easier to remember. At the same time, particular care was given so that the memory test at level D1 is not too easy, and the memory test at level D3 not too difficult. The numbers in the $3 \times 2$ matrix consisted of 389 and 647 ; the numbers in the $3 \times 3$ matrix consisted of $582,316,745$; the numbers in the $4 \times 3$ matrix consisted of 1435, 2518 and 6397. These tests were applied to a group of 10 students with similar characteristics to the study group, and the significance of the test was verified. During this process, the students were asked to look at the cards for 10 seconds, after which the cards were flipped facedown. The students were then asked to write the corresponding numbers in the blanks next to the cards. After each correct answer, the student advanced to next level question. Students were given three tries for each level. Upon failing to find the correct answer, no more questions were asked to the student. In addition, the kakuro tests in the field have been examined and a total of three kakuro tests with the difficulty levels of D1, D2 and D3 respectively, have been used.

Experts were consulted in order to determine the connection of these tests, which were prepared according to the MoNE game types of 2013, and which were judged to be a good measure of reasoning ability, with Parks' (2009) skills in the Map of Intellectual Domains. Five instructors in the field of mathematics education and gifted education were given detailed information about the preparation as 
well as application of these tests and asked to score them from 1 to 5 for each skill. As in Parks' (2009) Intellectual Domain Map skills are interconnected; a game improving one skill will result in the improvement of other skills as well. Therefore, it has been deemed appropriate to use 1 as the lowest score instead of 0 . The content validity ratio of the testes was calculated by the technique developed by Lawshe (1975) and the values obtained are presented in Table 2.

\section{Table 2}

The content validity of the tests used in the research

\begin{tabular}{lccccc}
\hline \multirow{2}{*}{ Content validity ratio } & \multicolumn{5}{c}{ Skills } \\
\cline { 2 - 6 } & $\begin{array}{c}\text { Creative } \\
\text { Thinking }\end{array}$ & $\begin{array}{c}\text { Analytical } \\
\text { Thinking }\end{array}$ & $\begin{array}{c}\text { Critical } \\
\text { Thinking }\end{array}$ & $\begin{array}{c}\text { Decision- } \\
\text { making }\end{array}$ & $\begin{array}{c}\text { Problem } \\
\text { Solving }\end{array}$ \\
\hline ACD Test & 0.6 & 1 & 1 & 1 & 0.2 \\
\hline Kakuro Test & 0.6 & 1 & 1 & 1 & 1 \\
\hline Memory Game Test & -0.6 & -0.2 & -0.2 & 0.6 & -1 \\
\hline
\end{tabular}

According to Lawshe technique, it was emphasized that the minimum content validity value of .99 was found to be appropriate at the 0.05 significance level for five experts (Veneziano \& Hooper, 1997). Therefore, it has been observed that the content validity ratio of ACD test and Kakuro test were very high for analytical thinking, critical thinking and decision-making skills. In line with the opinions of the experts, it was decided to remove the Memory Game Test from application and to use ACD Test and Kakuro Test to measure analytical, critical, decision-making skills of gifted students. On the other hand, in line with Parks (2009)'s Intellectual Domain Map, it is said that thinking skills interrelated and it is not possible to separate them completely from each other. Therefore, it is said that ACD Test and Kakuro Test used in the research measure the skills of creative thinking and problem solving, albeit to a lower level than the others.

After the preparation of the tests, the research proceeded with the application of the tests on gifted students. At first, the students were handed out the ACD Test (appendix 1) and were asked to complete it within 30 minutes. After the completion of the test, students could have a 15-minute break so that they do not get bored and lose motivation. After the break, these students, who were highly ready for the Kakuro test, were briefly informed about the game. After that, it was assumed that the kakuro test was understood and the students asked to do the Kakuro test within 20 minutes. After the tests were applied, the students were asked to play "Rat a Tat Cat" and "Sleeping Queens" 16 hours for 4 weeks, 4 hours per week. Rat-a-Tat Cat is a memory game developed by Monty and Ann Stambler and released by Gamewright. The game was awarded Mensa Select in 1996. Sleeping Queens is a students' card game developed by Gamewright. The idea of this game first came into Miranda Evarts' mind, when she was having trouble falling asleep. Her parents helped her develop the game and find a publisher. Sleeping Queens (SQ), was awarded "Best Wager Awards 2006" by the Canadian Toy Testing Council (Wikipedia, 2017).

These games, which are believed to improve intellectual thinking, critical thinking and decisionmaking skills, were played with students first with the participation of a researcher and followed by the students playing by themselves under the guidance of the said researcher. After the 4-week activity period, the implementation stage of the last test began. The students were subjected to the same tests as in the pre-test and the results were recorded. Furthermore, the data of students who did not participate in at least four hours of the course were not taken into consideration. During the evaluation of the data, various scoring systems were used. For the ACD test which consists of 18 items, a scoring of 1 for a correct answer and 0 for an incorrect answer was used. For the scoring of the Kakuro test, on the other hand, an analytical rubric prepared by the researchers was used. In the developed rubric, three evaluation 
scales for questions in each stage were used: Unsatisfactory (0), Needs Improvement (1), Satisfactory (2).

\section{Data Analysis}

Since "single group pre-test - post-test experimental pattern" was used in the research, the study was conducted with single group (study group). During the stage of data analysis, it was primarily investigated whether the data received from the students within the study group corresponded to the parametric test assumptions. The normal distribution of the data, which is the parametric assumption of the data received from the students of this group, and the homogeneity of the variances were tested statistically. Whether or not the data acquired from the groups varied normally was verified through the "coefficients of kurtosis and skewness" and "Kolmogorov-Smirnov test"; and the homogeneity of the variances verified through "Levene's Test of Equality of Error Variances". The graphics were also examined for normality testing. Since the Shapiro-Wilk test and Levene test showed that the p values were lower than 0.05 , it can be said that the distribution of data is not normal and the variances are not homogenous. Since it was observed after the analyses that the data did not meet the parametric test conditions, non-parametric statistics were used. "Wilcoxon Signed-Rank Test" was used to determine whether there was a significant difference between the pre-test and post-test scores of the students in the study group, who took the ACD Test and Kakuro Test. Although the significance level was taken as 0.01 in the research, the effect size was calculated to test the significance of the changes emerged after the application for the variables used. Significant differences between the averages of the scores do not guarantee actual difference in practice. For this reason, it is necessary to use effect size statistics in interpreting the results of the tests based on the comparison of average scores. Effect size calculation varies depending on the test applied. Regardless of the sign, the Cohen $d$ value used to calculate the effect size is interpreted as small, medium and large effect sizes of $0.2,0.5$ and 0.8 , respectively (Cohen, 1988). Analysis of the data in the study was conducted in the SPSS 16.0 package program.

\section{Findings}

In this section, findings obtained from analysis of research data are presented in tables. The Wilcoxon signed rank test results as to whether students' analytical thinking, critical thinking and decision-making skills differ significantly before and after the experiment was shown in Table 3.

Table 3

Wilcoxon Signed-rank Test results of ACD Test scores before and after experiment

\begin{tabular}{|c|c|c|c|c|c|c|c|}
\hline $\begin{array}{c}\text { ACD Test } \\
\text { (Levels) }\end{array}$ & $\begin{array}{l}\text { Pretest- } \\
\text { Posttest }\end{array}$ & $\mathbf{n}$ & Rank average & Rank total & $\mathbf{z}$ & $\mathbf{p}$ & $\begin{array}{c}\mathbf{r} \\
\text { (effect } \\
\text { size) }\end{array}$ \\
\hline \multirow{3}{*}{ 1st level } & Negative rank & 1 & 5.50 & 5.50 & $3.47^{*}$ & $0.00 * *$ & 0.74 \\
\hline & Positive rank & 15 & 8.70 & 130.50 & & & \\
\hline & Equal & 6 & & & & & \\
\hline \multirow{3}{*}{ 2nd level } & Negative rank & 0 & 0.00 & 0.00 & $3.77^{*}$ & $0.00 * *$ & 0.80 \\
\hline & Positive rank & 18 & 9.50 & 171.00 & & & \\
\hline & Equal & 4 & & & & & \\
\hline \multirow{3}{*}{ 3rd level } & Negative rank & 2 & 4.00 & 8.00 & $2.97^{*}$ & $0.00 * *$ & 0.63 \\
\hline & Positive rank & 13 & 8.62 & 112.00 & & & \\
\hline & Equal & 7 & & & & & \\
\hline \multirow{3}{*}{ Total } & Negative rank & 0 & 0.00 & 0.00 & $4.04^{*}$ & $0.00 * *$ & 0.86 \\
\hline & Positive rank & 21 & 11.00 & 231.00 & & & \\
\hline & Equal & 1 & & & & & \\
\hline
\end{tabular}

*Based on negative ranks ** $\mathrm{p}<0.01$

The results of the analysis showed that the pre-test and post-test scores of ACD test by level, which were respectively $\left(\mathrm{z}_{3 . \text { düzey }}=3,47, \mathrm{z}_{1 \text {.dïzey }}=3,77, \mathrm{z}_{2 \text {.düzey }}=2,97 ; \mathrm{p}<0,01\right)$ and the total test scores $(\mathrm{z}$ $=4.04 ; \mathrm{p}<0.01)$ differed quite significantly. When the rank averages and sums of the difference scores are taken into consideration, it is seen that this difference is in favor of the positive rank, that is, the 
final test score. However, when the effect size ( $r$ ) values are examined, it can be said that the effect is generally high at all levels and in terms of total test scores, in other words, it can be concluded that the difference between pre-test post-test scores is great. According to these results obtained by the ACD test, it can be said that mind games played with students play an important role in improving students' analytical thinking, critical thinking and decision-making skills.

The Wilcoxon signed rank test results as to whether students' analytical thinking, critical thinking and decision-making skills differ significantly before and after the experiment is shown in Table 4.

\section{Table 4}

Wilcoxon Signed-ranks Test results of Kakuro Test scores before and after experiment

\begin{tabular}{|c|c|c|c|c|c|c|c|}
\hline $\begin{array}{c}\text { Kakuro Test } \\
\text { (Levels) }\end{array}$ & $\begin{array}{l}\text { Pretest- } \\
\text { Posttest }\end{array}$ & $\mathbf{n}$ & Rank average & Rank total & $\mathbf{z}$ & $\mathbf{p}$ & $\mathbf{R}$ \\
\hline \multirow{3}{*}{$\begin{array}{c}\text { 1st level } \\
\text { (Small) }\end{array}$} & Negative rank & 0 & 0.00 & 0.00 & \multirow[t]{3}{*}{$2.88^{*}$} & \multirow[t]{3}{*}{$0.00 * *$} & \multirow[t]{3}{*}{0.61} \\
\hline & Positive rank & 10 & 5.50 & 55.00 & & & \\
\hline & Equal & 12 & & & & & \\
\hline \multirow{3}{*}{$\begin{array}{l}\text { 2nd level } \\
\text { (Medium) }\end{array}$} & Negative rank & 0 & 0.00 & 0.00 & \multirow[t]{3}{*}{$3.62^{*}$} & \multirow[t]{3}{*}{$0.00 * *$} & \multirow[t]{3}{*}{0.77} \\
\hline & Positive rank & 16 & 8.50 & 136.00 & & & \\
\hline & Equal & 6 & & & & & \\
\hline \multirow{3}{*}{$\begin{array}{c}\text { 3rd level } \\
\text { (Large) }\end{array}$} & Negative rank & 0 & 0.00 & 0.00 & \multirow[t]{3}{*}{$2.76^{*}$} & \multirow[t]{3}{*}{$0.00 * *$} & \multirow[t]{3}{*}{0.59} \\
\hline & Positive rank & 9 & 5.00 & 45.00 & & & \\
\hline & Equal & 13 & & & & & \\
\hline \multirow{3}{*}{ Total } & Negative rank & 0 & 0.00 & 0.00 & \multirow[t]{3}{*}{$4.04^{*}$} & \multirow[t]{3}{*}{$0.00 * *$} & \multirow[t]{3}{*}{0.86} \\
\hline & Positive rank & 21 & 11.00 & 231.00 & & & \\
\hline & Equal & 1 & & & & & \\
\hline
\end{tabular}

The results of the analysis showed that the pre-test and post-test scores of the Kakuro Test by level, which were respectively $\left(\mathrm{z}_{1 . \text { düzey }}=2,88, \mathrm{z}_{2 . \text { düzey }}=3,62, \mathrm{z}_{3 \text {.düzey }}=2,76 ; \mathrm{p}<0,01\right)$ and the total test scores $(\mathrm{z}=4.04 ; \mathrm{p}<0.01)$ differed quite significantly. When the rank averages and sums of the difference scores are taken into consideration, it is seen that this difference is in favor of the positive rank, that is, the final test score. However, when the effect size (r) values are examined, it can be said that the effect is moderate to high at all levels and in terms of total test scores, in other words, it can be concluded that the difference between pre-test post-test scores is great. According to these results obtained by the Kakuro Test, it can be said that mind games played with students play an important role in improving students' analytical thinking, critical thinking and decision-making skills.

\section{Discussion, Conclusion and Recommendations}

The data obtained in the research reveal that various mind games played with the identified gifted students in the elementary school age increase their analytical thinking, critical thinking and decision making skills. As a result of the analysis made in this direction, it was seen that there was a significant difference between the pre-test and post-test scores of ACD Test and Kakuro Test as well as the total test scores. What's more, it can be said that the effect is high in the general sense, in other words, the difference between pre-test and post-test scores is large. Fun and motivating games that people of all ages love, give students the opportunity to explore basic notions such as number concepts, one to one matching and calculation strategies. Furthermore, mathematical games allow students to deepen their reasoning skills, which are closely related to mathematical understanding and skills in the Parks (2009) Map of the Intellectual Domain (Rutherford, 2015). Procedural fluency and conceptual understanding can be improved through problem-solving, reasoning, and discussion skills (National Council of Teachers of Mathematics [NCTM], 2000). Games can create an environment in which students develop mathematical reasoning skills (Rutherford, 2015). Devecioğlu and Karadağ (2014)'s studies on lessons about mind games show that mind games not only include games affecting the development of mathematics but also games that develop calculative and strategic strength improving skills such as verbal and visual intelligence, problem-solving, finding solutions, three-dimensional thinking, 
designing, forming shapes, tactical development, critical thinking and creativity. In Kurbal's work (2015), it was found that mind games improved students' problem solving and reasoning skills. Strom and Barolo (2011) examined the effect of the game they used in the study (mastermind) on reasoning skills and observed that it had a positive effect. Reiter, Thornton and Vennebush (2014) mentioned in their study that the 'kendoku' game improved the reasoning skills. They point out that the reasoning skills important in mathematics and other lessons as well as everyday life, are improved through playing this game. McFarlane, Sparrowhawk, \& Heald (2002) found that games used in education helped students gain autonomy. They have also concluded that educational games improved the students' memory, as well as help them gain problem-solving and reasoning skills. They also reported that they were more accustomed to group work. What's more, Kafai (2006) stated that educational games contributed to the interpretation skills of the students. Bottino and Ott (2006) and Bottino, Ott, Tavella \& Benigno (2010) and Bottino, Ott \& Benigno (2009) and Bottino, Ott \& Tavella (2013) have shown that mind games increase students' academic success in their courses and contribute to their reasoning skills. As noted above, the idea that games improve the students' reasoning ability as well as analytical thinking, critical thinking and decision-making skills closely connected in the Parks (2009) Intellectual Domain Map, is supported by relevant studies in the field as well.

It is seen that gifted students use more strategies than those who are not to solve the problem and have a flexible mindset in implementing these strategies (Y1ld1z, 2012). In addition, it is suggested that gifted students first express problems with their own words during the problem-solving process, and then put forward new ideas by offering the necessary conditions for the solution (Baltaci, 2016). With this explanation made, the importance of these skills in our daily lives has been stressed. In this respect, it has been emphasized that these skills, which are expressed through games played with elementary school students in the research, can be developed and their development is of utmost importance.

In the field, it is known that mind development may be easier and faster at early ages (Senemoğlu, 2011). In line with this, teaching mind games in public schools or private schools as elective courses in primary schools is recommended. The importance of shifting mind games that are being taught in public middle schools as elective courses to a younger age group has been supported by various studies in the field as mentioned above. This research focused on analytical thinking, critical thinking and decisionmaking skills. Future studies may also examine the effect of mind games on different intellectual skills/daily life skills of student groups at different levels or focus on the effects of mind games on affective properties. In this study, students were asked to play "Rat a Tat Cat" and "Sleeping Queens," which are the most used mind games in the US. The effects of different mind games and mind game types on these skills can also be further researched. Also, this research was conducted on gifted students. Future studies may involve students with normal IQ levels and the effects of mind games on both groups can be examined comparatively.

\section{References}

Altun, M. (2017). The effects of the physical activity cards and brain teasers to the attention and visual perception levels of the primary school students (Unpublished doctoral thesis). Gazi University Institute of Educational Sciences, Ankara.

Baki, N. (2018). The effect of the geometrical- mechanical games applied in intelligent games lesson on students' academic self- efficacy and problem solving ability (Unpublished master thesis). Kırıkkale University Institute of Educational Sciences, Kırıkkale.

Baltaci, S. (2016). Examination of Gifted Students' Probability Problem Solving Process in Terms of Mathematical Thinking. Malaysian Online Journal of Educational Technology, 4(4), 18-35.

Bottino, R.M., \& Ott, M. (2006). Mind games, reasoning skills, and the primary school curriculum: hints from a field experiment. Learning Media \& Technology, 31(4), 359-375.

Bottino, R. M., Ott, M., \& Benigno, V. (2009). Digital mind games: experience based reflections on design and interface features supporting the development of reasoning skills. In Proceedings of the 3rd European Conference on game based learning (pp. 53-61). 
Bottino, R. M., Ott, M., Tavella, M., \& Benigno, V. (2010). Can digital mind games be used to investigate students' reasoning abilities. In Proceedings of the 4th ECGBL Conference on Games Based Learning Copenhagen, Denmark, Academic, Conferences, 31(10), 31-39

Bottino, R. M., Ott, M., \& Tavella, M. (2013). Investigating the relationship between school performance and the abilities to play mind games. In Proceedings of the European conference on games based learning (pp. 6271).

Bulut, A.S. (2018). Prospective Primary School Teachers' Perceptions about Highly Talented Individuals and Concepts of Special Education. Journal of Kirsehir Education Faculty, 19(3), 2357-2376.

Büyüköztürk, Ş., Kılıç Çakmak, E., Akgün, Ö.E., Karadeniz, Ş., \& Demirel, F. (2012). Scientific research methods (12. Edition). Ankara: Pegem Publication.

Cameron, J. (2007). IQ mindbenders. Arcturus Publishing Limited.

Cohen, J. (1988). Statistical power analysis for the behavioral sciences (2nd ed.). Hillsdale, NJ: Erlbaum.

Conelly, R. J. (2002). Using cooperative games as student motivation. (Unpublished Master Thesis). USA: The Faculty of Pacific Lutheran University. Retrieved from http://proquest.umi.com. At July, 2015.

Çepni, S., Bayrakçeken, S., Yılmaz, A., Yücel, C., Semerci, Ç., Köse, E., Sezgin, F., Demircioğlu, G. \& Gündoğdu, K. (2008). Assessment and evaluation. Ankara: Pegem Academy.

Demirel, T., \& Karakuş Yılmaz, T. (2019). The effects of mind games in math and grammar courses on the achievements and perceived problem-solving skills of secondary school students. British Journal of Educational Technology, 50(3), 1482-1494.

Devecioğlu, Y., \& Karadağ, Z. (2014). Assessment of mind games course in terms of purpose, expectations and suggestions. Bayburt University Journal of Education, 9 (1), 41-61.

Erhan, E., Hazar, M., \& Tekin, M. (2009) An assessment of the problem solving skills of primary school students playing chess and not playing chess. Atabesbd, 11 (2), 1-8. Accessed from edergi.atauni.edu.tr/ ataunibesyo/article/view/1025002520 on July 2015.

Gauvrit, N. (2014) Pourquoi tant de personnes ont du mal a retenir combien font 7x8, Atlantico, Retrieved from http://www.atlantico.fr/decryptage/pourquoi-tant-personnes-ont-mal-retenircombien-font-7-fois-8-nicolas-gauvrit-1653871.html\#PSCcS3BdU42PlwIu.99 at March 2016.

Genç, H., \& Dağlığlu, E. H. (2018). Erken çocukluk döneminde üstün yetenekli çocuklar ve oyun. Eğitim ve Toplum Araştırmaları Dergisi, 5(1), 180-204.

Kafai, Y. (2006) Playing and making games for learning: instructionist and constructionist perspectives for game studies, Games and Culture, 1, 36-40.

Kirriemuir, J., \& McFarlane, A. (2004) Literature review in games and learning, University of Bristol: England: A NESTA Futurelab Research report - report 8.

Kurbal, M. S. (2015). An investigation of sixth grade students' problem solving strategies and underlying reasoning in the context of a course on general puzzles and games. (Unpublished Master Thesis), Ankara: Middle East Technical University.

Lawshe, C. H. (1975). A quantitative approach to content validity. Personnel Psychology, 28, 563-575.

Marangoz, D., \&. Demirtaş, Z. (2017). The effect of mechanical mind games on mental skill levels of primary school second grade students. The Journal of International Social Research, 10(53), 612621.

McFarlane, A., Sparrowhawk, A., \& Heald, Y. (2002). Report on the educational use of games. TEEM (Teachers Evaluating Educational Multimedia), Cambridge. 
MoNE. (2013). 5th, 6th, 7th and 8th grades intelligence games lesson curriculum. Ministry of National Education, Board of Education and Discipline, Ankara.

NCTM. (2000). Priciples and standarts for school mathematics. Reston, VA: NCTM.

Oğurlu, Ü. \& Yaman, Y. (2010). Gifted students and communication. Pamukkale University Education Faculty Journal, 28 (II), 213-223.

Parks, S. (2009). Methods and materials for teaching the gifted. F. A. Karnes \& S. M. Bean. (Eds.) $3^{\text {th }}$ edition. USA: Prufrock Press Inc.

Polat, S. (2013). Teaching mathematics with origami. Mustafa Kemal University Journal of Social Sciences Institute, 10 (21), 15-27.

Reiter, H. B., Thornton, J., \& Vennebush, G. P. (2014). Using KenKen to build reasoning skills. Mathematics Teacher, 107(5), 341-347.

Rutherford, K. (2015). Why play math games? Retrieved from http://www.nctm.org/publications/teac hing-students-mathematics/blog/why-play-math-games_/

Senemoğlu, N. (2011). Development, learning and teaching application from the theory. Ankara: Pegem Pub.

Strom, A., \& Barolo, S. (2011). Using the game of mastermind to teach, practice, and discuss scientific reasoning skills. PLoS Biology, 9(1), e1000578.

Veneziano L., \& Hooper J. (1997). "A method for quantifying content validity of health-related questionnaires". American Journal of Health Behavior, 21(1):67-70.

Wikipedia (2017). Rat-a-Tat Cat \& Sleeping Queens. Retrieved from en.wikipedia.org At March 2017.

Yıldız, A., Baltacı, S., Kurak, Y., \& Güven, B. (2012). Examining The Usage Of Problem-Solving Strategies By The Eighth Grade Gifted And Non-Gifted Students. Journal of Uludag University Faculty of Education, 25(1), 123-143. 
ACD Test (Appendix 1)
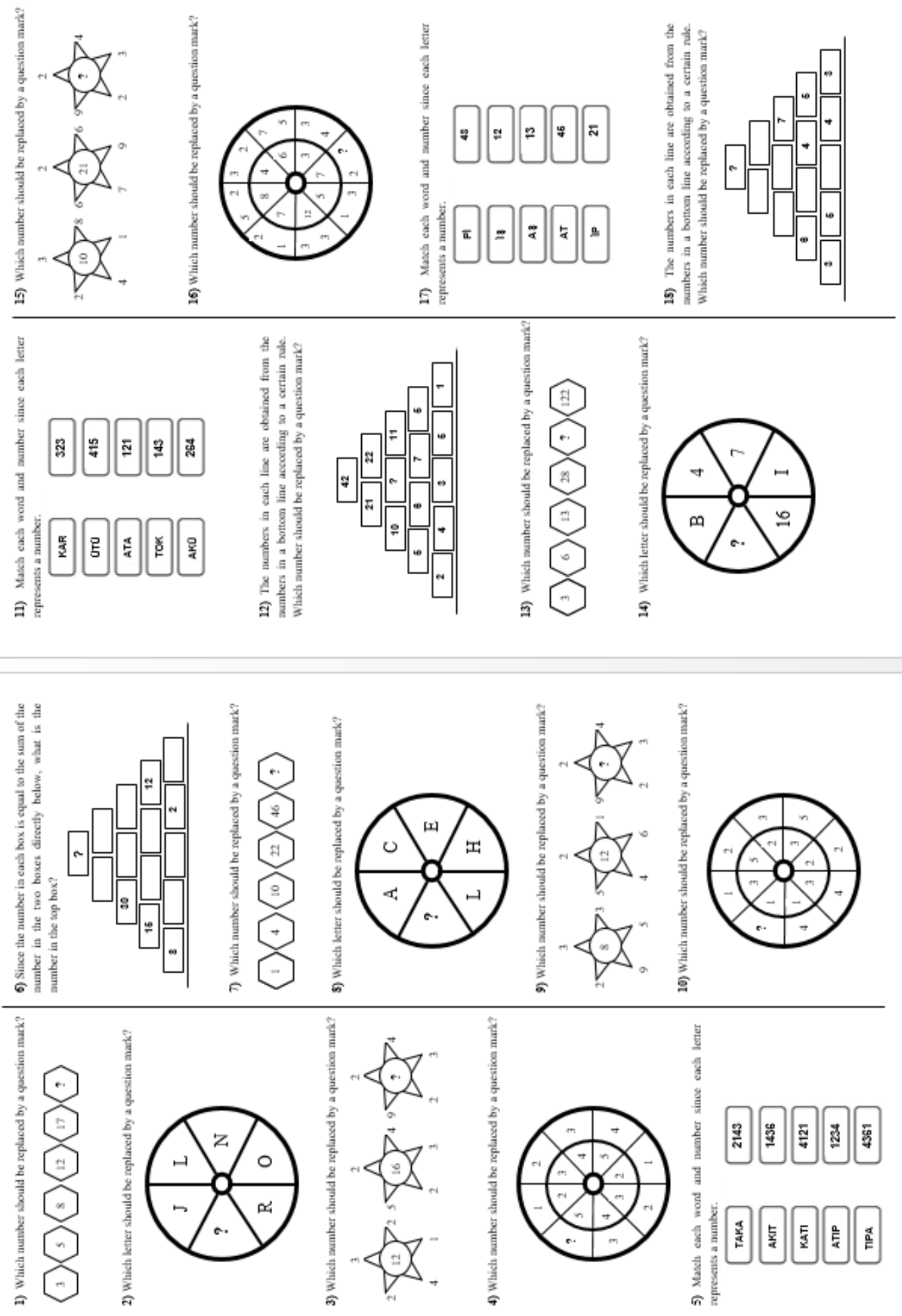
